\title{
Quantification of ikaite in Antarctic sea ice
}

\section{MICHAEL FISCHER ${ }^{1}$, DAVID N. THOMAS ${ }^{2,3,4}$, ANDREAS KRELL ${ }^{1}$, GERNOT NEHRKE ${ }^{1}$, JÖRG GÖTTLICHER ${ }^{5}$, LOUIZA NORMAN ${ }^{2}$, KLAUS M. MEINERS ${ }^{6,7}$, CATHERINE RIAUX-GOBIN $^{8}$ and GERHARD S. DIECKMANN ${ }^{1}$}

\author{
${ }^{I}$ Alfred Wegener Institute for Polar and Marine Research, Am Handelshafen 12, 27570 Bremerhaven, Germany \\ ${ }^{2}$ Ocean Sciences, College of Natural Sciences, Bangor University, Menai Bridge, Anglesey LL59 5AB, UK \\ ${ }^{3}$ Marine Centre, Finnish Environment Institute (SYKE), PO Box 140, FI-00251 Helsinki, Finland \\ ${ }^{4}$ Arctic Research Centre, Aarhus University, Aarhus, Denmark \\ ${ }^{5}$ Institute of Synchrotron Radiation (ISS), Synchrotron Radiation Source ANKA, Karlsruhe Institute of Technology, \\ Hermann-von-Helmholtz-Platz 1, 76344 Eggenstein-Leopoldshafen, Germany \\ ${ }^{6}$ Australian Antarctic Division, Department of Sustainability, Environment, Water, Population and Communities, Channel Highway, \\ Kingston, TAS 7050, Australia \\ ${ }^{7}$ Antarctic Climate and Ecosystems Co-operative Research Centre, Private Bag 80, Hobart, TAS 7001, Australia \\ ${ }^{8}$ USR3278, CRIOBE, CNRS-EPHE, 52 Avenue Paul Alduy, 66860 Perpignan, France \\ michael.fischer@awi.de
}

\begin{abstract}
Calcium carbonate precipitation in sea ice is thought to potentially drive significant $\mathrm{CO}_{2}$ uptake by the ocean. However, little is known about the quantitative spatial and temporal distribution of $\mathrm{CaCO}_{3}$ within sea ice, although it is hypothesized that high quantities of dissolved organic matter and/or phosphate (common in sea ice) may inhibit its formation. In this quantitative study of hydrous calcium carbonate as ikaite, sea ice cores and brine samples were collected from pack and land fast sea ice between September and December 2007 during two expeditions, one in the East Antarctic sector and the other off Terre Adélie. Samples were analysed for $\mathrm{CaCO}_{3}$, salinity, dissolved organic carbon/nitrogen, inorganic phosphate, and total alkalinity. No relationship between these parameters and $\mathrm{CaCO}_{3}$ precipitation was evident. Ikaite was found mostly in the uppermost layers of sea ice with maximum concentrations of up to $126 \mathrm{mg}$ ikaite per litre melted sea ice being measured, although both the temporal and horizontal spatial distributions of ikaite were highly heterogeneous. The precipitate was also found in the snow on top of the sea ice at some of the sampling locations.
\end{abstract}

Received 2 July 2012, accepted 6 November 2012, first published online 20 December 2012

Key words: biogeochemistry, brine, calcium carbonate precipitation, inorganic carbon cycle, nutrients, Southern Ocean

\section{Introduction}

Sea ice covers up to $7 \%$ of the total surface area of the oceans at its maximum extent (Comiso 2010). The physical barrier itself has a major impact on the gas exchange between atmosphere and ocean, and recently the discussion has extended to considering how physical and biogeochemical processes within the ice itself can affect diffusion and flux of gases to both atmosphere and ocean (Rysgaard et al. 2007, 2009, 2011, Miller et al. 2011, Loose et al. 2011). On the basis of thermodynamic equilibrium calculations, the precipitation of $\mathrm{CaCO}_{3}$ was predicted to occur during natural sea ice formation (Jones \& Coote 1981, Anderson \& Jones 1985 ) and it was proposed to precipitate as calcite (Marion 2001). However, actual evidence was, for a long time, only indirect (Killawee et al. 1998, Papadimitriou et al. 2004, 2012) until Dieckmann et al. (2008) found calcium carbonate as ikaite $\mathrm{CaCO}_{3}{ }^{*} 6 \mathrm{H}_{2} \mathrm{O}$ in Antarctic sea ice, and more recently in Arctic sea ice (Dieckmann et al. 2010, Rysgaard et al. 2012). Rysgaard et al. (2007, 2009) showed that with brine, dissolved inorganic carbon (DIC) is rejected from growing sea ice to the underlying waters. They ascribe the high $\mathrm{pCO}_{2}$ (partial pressure of $\mathrm{CO}_{2}$ ) levels found below sea ice to calcium carbonate precipitation. Rysgaard et al. (2007) proposed that $\mathrm{CaCO}_{3}$ precipitation in sea ice could result in a significant $\mathrm{CO}_{2}$ uptake by the ocean and therefore contribute to a polar carbon pump.

Besides its function as a component in the carbon cycle, the mineral is also thought to have a key role in tropospheric ozone depletion events (ODEs) at high latitudes (Sander et al. 2006, Sander \& Morin 2010). Simulations of the chemistry occurring in Polar Regions over newly formed sea ice relate the ODE to the transformation of inert sea-salt bromide to reactive bromine monoxide $(\mathrm{BrO})$ when precipitation of calcium carbonate from freezing seawater is taken into account. The discovery of ikaite in firn ice of the Antarctic continent, which appears to be derived from sea ice $300 \mathrm{~km}$ away, may also have implications for its use as a sea ice proxy (Sala et al. 2008). However, to date most studies of calcium carbonate in sea ice have been mainly qualitative and 


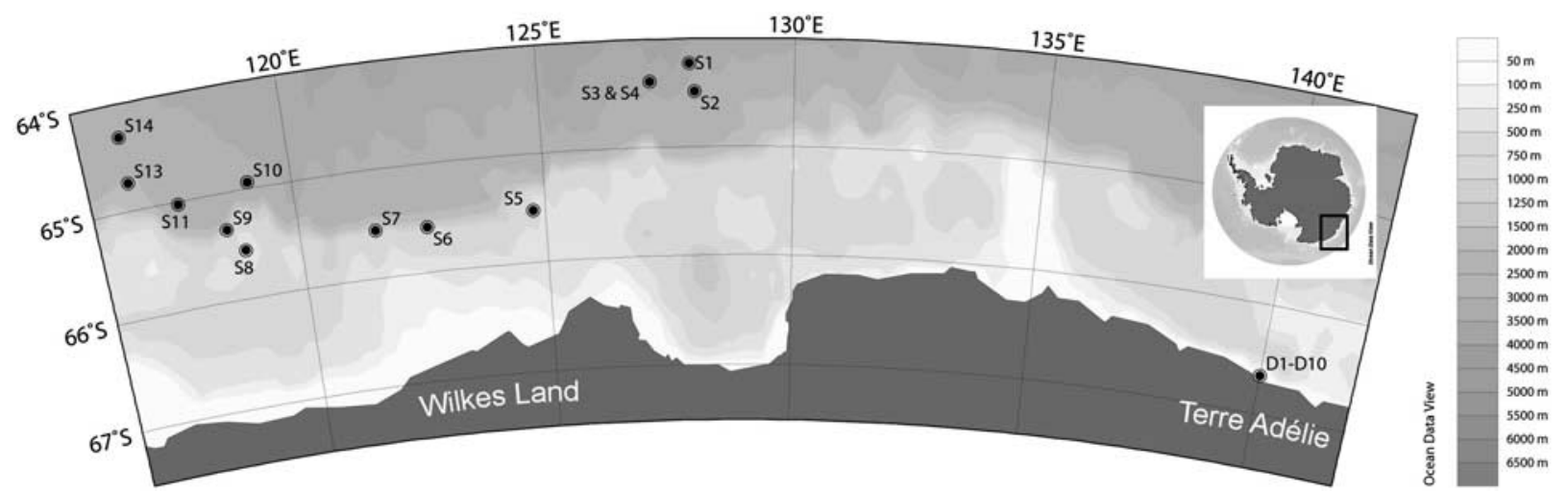

Fig. 1. Locations of ice stations sampled during Sea Ice Physics and Ecosystem eXperiment (SIPEX) and Dumont d'Urville (DDU) campaigns.

little is known about the spatial and temporal distribution of $\mathrm{CaCO}_{3}$ within sea ice.

There is also a lack of knowledge on the exact conditions leading to ikaite precipitation as well as on the amount and fate of ikaite, e.g. one assumption is that phosphate and dissolved organic matter (DOM) may reduce the precipitation of calcium carbonate (Zullig \& Morse 1988, Bischoff et al. 1993). Both dissolved inorganic phosphate

Table I. Sample types and thickness of sea ice during Sea Ice Physics and Ecosystem eXperiment (SIPEX) and Dumont d'Urville (DDU) campaigns. $\mathrm{N} / \mathrm{A}=$ data not available.

\begin{tabular}{|c|c|c|c|c|c|c|c|}
\hline Sample & Cruise & Date & $\begin{array}{l}\text { Time } \\
\text { (UTC) }\end{array}$ & $\begin{array}{l}\mathrm{T}_{\text {air }} \\
\left({ }^{\circ} \mathrm{C}\right)\end{array}$ & $\begin{array}{c}\mathrm{T} \text { at } 5 \mathrm{~cm} \\
\text { below surface } \\
\left({ }^{\circ} \mathrm{C}\right)\end{array}$ & Sample type & $\begin{array}{l}\text { Sample } \\
\text { thickness } \\
(\mathrm{cm})\end{array}$ \\
\hline S2 & SIPEX & 12.09.2007 & 06:00 & -18.6 & -9.6 & Pack ice, brine from sackhole & 98 \\
\hline S3 & SIPEX & 14.09 .2007 & 06:00 & -20.1 & -11.7 & Pack ice, brine from sackhole & 49 \\
\hline S4 & SIPEX & 17.09.2007 & 08:00 & -19.0 & N/A & Pack ice, brine from sackhole & 55 \\
\hline S5 & SIPEX & 18.09.2007 & 08:00 & -18.0 & -10.2 & Fast ice between grounded icebergs, brine from sackhole & 85 \\
\hline S7 & SIPEX & 22.09 .2007 & $02: 30$ & -12.3 & -7.2 & Pack ice, brine from sackhole & 53 \\
\hline S8 & SIPEX & 25.09.2007 & 10:00 & -7.0 & -4.9 & Large level floe, brine from sackhole & 37 \\
\hline S9 & SIPEX & 28.09.2007 & 03:00 & -11.1 & -4.9 & Heavily rafted and deformed ice, brine from sackhole & 98 \\
\hline $\mathrm{S} 10$ & SIPEX & 30.09 .2007 & 04:00 & -14.8 & -4.0 & $\begin{array}{l}\text { Large level floe, coring site on an adjacent rafted area, probably } \\
\text { an old chunk caught by new ice, brine from sackhole }\end{array}$ & 133 \\
\hline S11 & SIPEX & 03.10 .2007 & 02:00 & -7.3 & -6.8 & $\begin{array}{l}\text { Rafted floe, ice surface very rough probably crushed together } \\
\text { pancakes at an earlier stage, brine from sackhole }\end{array}$ & 101 \\
\hline D1 & DDU & 14.11.2007 & N/A & -6.6 & -5.2 & Young (c. 3 month) fast ice, $10 \mathrm{~cm}$ sections & 65 \\
\hline D2 & DDU & 17.11.2007 & N/A & -3.2 & -4.1 & Young (c. 3 month) fast ice, $10 \mathrm{~cm}$ sections & 65 \\
\hline D3 & DDU & 23.11 .2007 & $\mathrm{~N} / \mathrm{A}$ & -5.9 & -5.2 & Young (c. 3 month) fast ice, $10 \mathrm{~cm}$ sections & 60 \\
\hline D4 & DDU & 24.11.2007 & N/A & -2.6 & N/A & Young (c. 3 month) fast ice, $10 \mathrm{~cm}$ sections & 60 \\
\hline D5 & DDU & 27.11.2007 & N/A & -2.9 & -5.1 & Young (c. 3 month) fast ice, $10 \mathrm{~cm}$ sections & 60 \\
\hline D6 & DDU & 03.12 .2007 & N/A & -4.6 & -2.9 & Young (c. 3 month) fast ice, $10 \mathrm{~cm}$ sections & 60 \\
\hline D7 & DDU & 23.11.2007 & N/A & -5.9 & -5.2 & Young (c. 3 month) fast ice, $2 \mathrm{~cm}$ sections & 10 \\
\hline D8 & DDU & 24.11.2007 & N/A & -2.6 & N/A & Young (c. 3 month) fast ice, $2 \mathrm{~cm}$ sections, snow on top & 16 \\
\hline D9 & DDU & 24.11.2007 & N/A & -2.6 & N/A & Young (c. 3 month) fast ice, $2 \mathrm{~cm}$ sections & 14 \\
\hline D10 & DDU & 05.12 .2007 & N/A & -2.0 & -5.4 & Fast ice (age $=1$ year), $2 \mathrm{~cm}$ sections & 16 \\
\hline D-SH1 & DDU & 14.11.2007 & N/A & -6.6 & -5.2 & Ice and brine samples from sackholes in fast ice & 30 \\
\hline D-SH2 & DDU & 17.11.2007 & N/A & -3.2 & -4.1 & Ice and brine samples from sackholes in fast ice & 30 \\
\hline
\end{tabular}




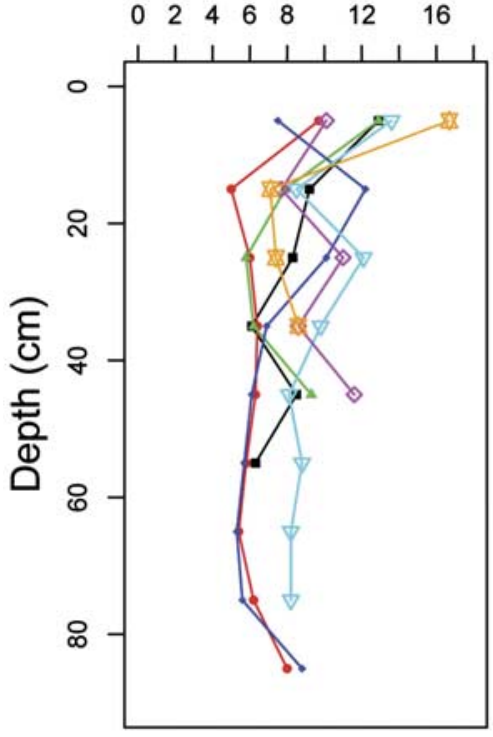

Salinity

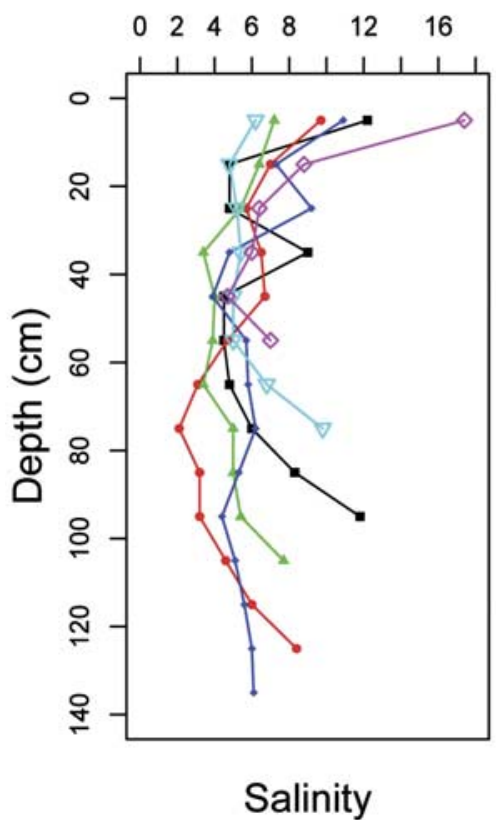

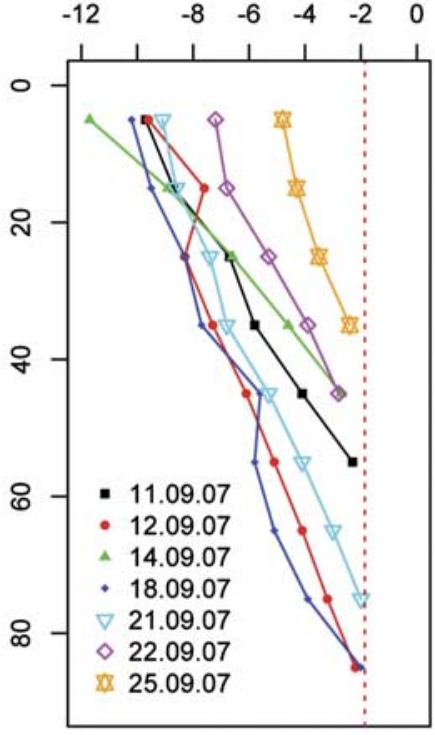

Temperature in ${ }^{\circ} \mathrm{C}$

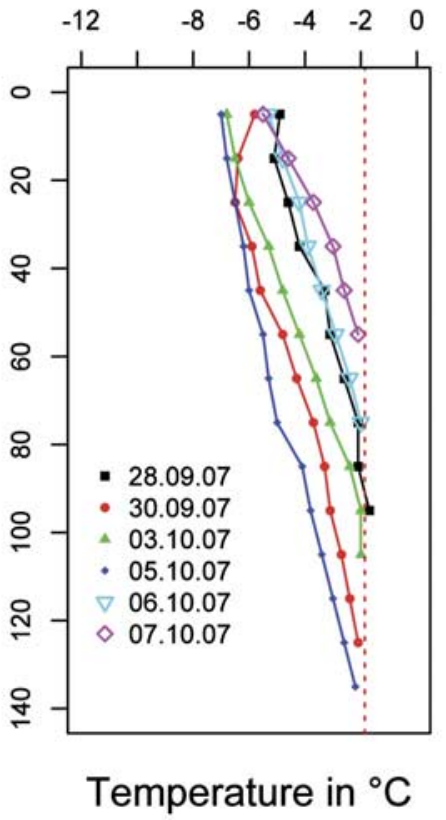

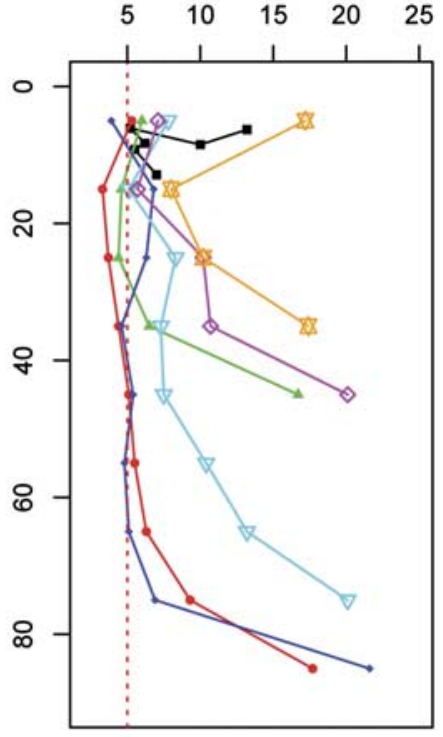

Brine Volume in \%

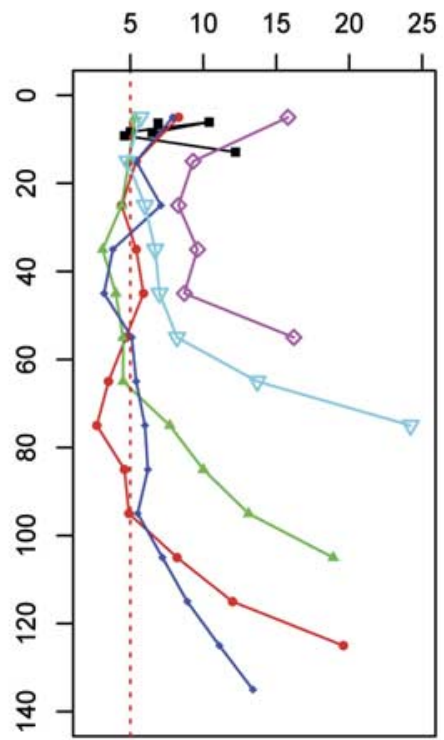

Brine Volume in \%

Fig. 2. Bulk salinity, sea ice temperature, and calculated (Cox \& Weeks 1986) brine volume in different ice cores taken between September and October 2007 in East Antarctic during SIPEX campaign.

and DOM can be present in sea ice in very high concentrations (Thomas et al. 2001), and it can be hypothesized that where these parameters are present in high concentrations that precipitation of some polymorphs of calcium carbonate will be inhibited.

The objective of this study therefore was to: 1) provide the first systematic observation and quantification of $\mathrm{CaCO}_{3}$ precipitation in Antarctic sea ice on a spatial and temporal scale, and 2) to investigate relationships between calcium carbonate and alkalinity, phosphate, and dissolved organic matter.

\section{Methods}

Two campaigns were performed between September and December 2007. During the first campaign (Sea Ice Physics and Ecosystem eXperiment (SIPEX) onboard RSV Aurora Australis from September-October 2007) 14 ice cores (S1-S14) were taken at different locations between $64^{\circ}$ and $66^{\circ} \mathrm{S}$, and $116^{\circ}$ and $128^{\circ} \mathrm{E}$ (Fig. 1). The cores were cut into $10 \mathrm{~cm}$ sections within a few minutes after sampling and stored in plastic containers. Ice cores from station S1-S4 and S6-S14 represent pack ice with different degrees of 

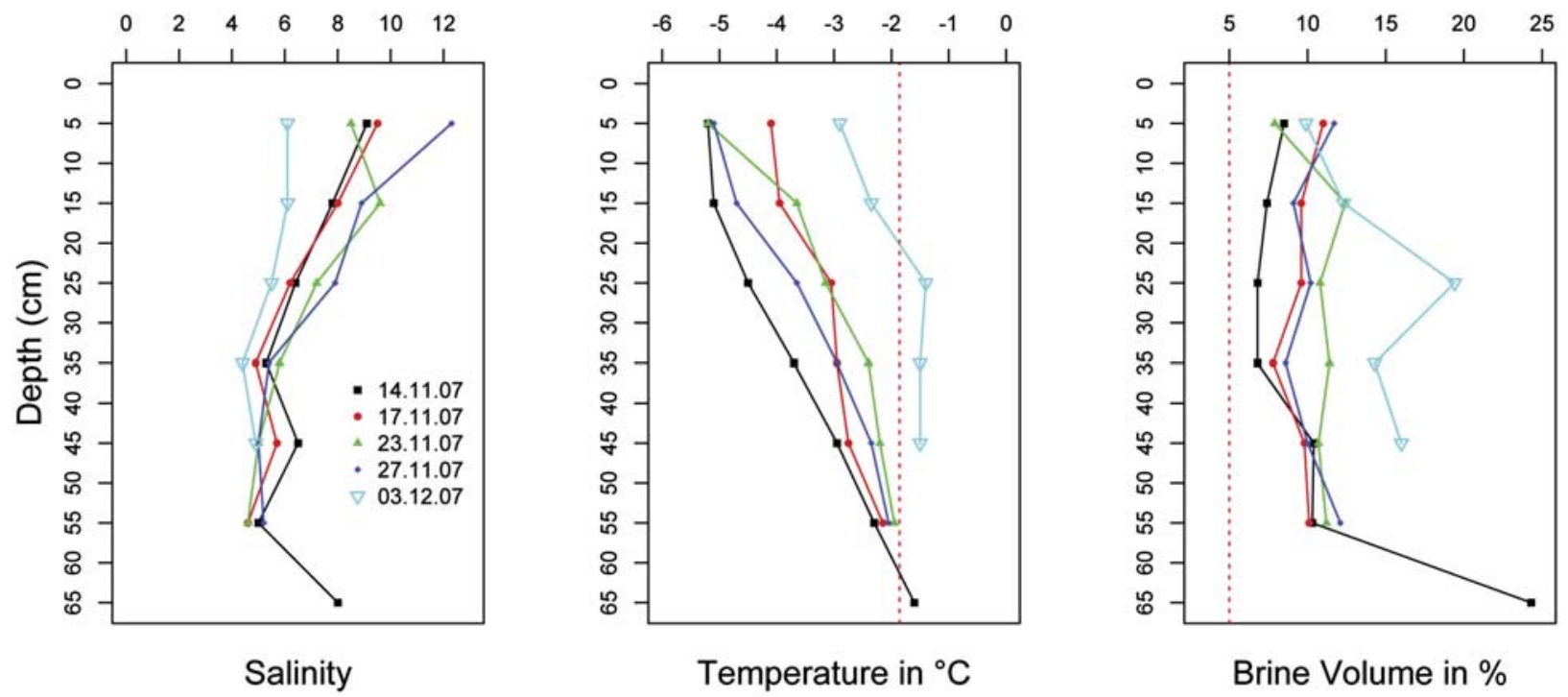

Fig. 3. Bulk salinity, sea ice temperature, and calculated (Cox \& Weeks 1986) brine volume in land fast sea ice cores taken between November and December 2007 in East Antarctic during Dumont d'Urville campaign.

deformation (Table I). The ice core from station S5 was taken from fast ice between grounded icebergs. For details on ice types, bulk salinity, ice temperature, and brine volume see Table I, Figs $2 \& 3$, and Meiners et al. (2011). A general description of the ice conditions during the expedition can be found in (Worby et al. 2011). Brine from sackholes from ten out of 14 stations (Table II) was collected for nutrient and DOM analyses (Norman et al. 2011).
During the second campaign (from November-December 2007) sea ice samples were collected close to the French Dumont d'Urville Base (DDU), 66 $39^{\circ} 13^{\prime \prime} \mathrm{S}, 140^{\circ} 00^{\prime} 5^{\prime \prime} \mathrm{E}$ near station C described in Delille et al. (2007). Six complete ice cores (D1-D6) were taken from young fast ice (age approximately three months, Anne Jacquet, personal communication 2007), which had formed in August. This area was predominantly free of snow with only isolated patches of snow being present. The cores were also cut into

Table II. Physico-chemical properties of brine collected from sackholes from land fast ice off Terre Adélie (Dumont d'Urville campaign) in November 2007 (D-SH1 to D-SH7) and from sea ice in East Antarctica (see map) between September and October 2007 (S1-S14). Total alkalinity (TA), dissolved organic nitrogen (DON), dissolved organic carbon (DOC), and nutrients are normalized to $\mathrm{S}=35$ and in $\mu \mathrm{mol} 1^{-1}$. Ikaite values are from ice cores $(30 \mathrm{~cm})$ obtained from the sackholes (D-SH1 to D-SH7, DDU campaign) and ice cores adjacent to the sackholes (S1-S14, SIPEX cruise, sum of the first three $10 \mathrm{~cm}$ sections) and presented in $\mathrm{mg} \mathrm{l}^{-1} . \mathrm{N} / \mathrm{A}=$ data not available.

\begin{tabular}{lccccccccrrrr}
\hline Sample & Date & $\mathrm{T}_{\text {Brine }}$ & $\mathrm{S}_{\mathrm{Brine}}$ & $\left(\mathrm{PO}_{4}{ }^{2-}\right)_{35}$ & $(\mathrm{Si})_{35}$ & $\left(\mathrm{NO}_{2}\right)_{35}$ & $\left(\mathrm{NO}_{2}\right)+\left(\mathrm{NO}_{3}\right)_{35}$ & $\left(\mathrm{SNH}_{4}{ }^{+}\right)_{35}$ & $\mathrm{DON}_{35}$ & $\mathrm{DOC}_{35}$ & $\mathrm{Ikaite}$ & $\mathrm{TA}_{35}$ \\
\hline D-SH1 & 14.11 .07 & -4.8 & 86 & 0.50 & 50.30 & 0.12 & 16.17 & 0.37 & 4.91 & 85.99 & 1.03 & 2573.79 \\
D-SH2 & 17.11 .07 & -4.0 & 76 & 1.53 & 41.39 & 0.14 & 10.63 & 2.04 & 17.50 & 146.17 & 0.68 & 2236.36 \\
D-SH3 & 18.11 .07 & -3.9 & 76 & 0.30 & 62.18 & 0.05 & 3.06 & 0.45 & 8.45 & 78.80 & 0.22 & 2370.92 \\
D-SH4 & 23.11 .07 & -4.0 & 74 & 1.33 & 53.12 & 0.07 & 3.11 & 0.91 & 33.41 & 180.04 & 1.23 & 2311.20 \\
D-SH5 & 25.11 .07 & -2.5 & 45 & 1.77 & 68.80 & 0.11 & 4.71 & 1.47 & 27.75 & 183.44 & 1.58 & 2171.08 \\
D-SH6 & 27.11 .07 & -3.6 & 65 & 0.45 & 49.83 & 0.08 & 0.98 & 0.32 & 12.51 & 130.84 & 0.53 & 2394.29 \\
D-SH7 & 03.12 .07 & -2.6 & 46 & 0.47 & 55.53 & 0.03 & 0.20 & 0.77 & 27.59 & 195.34 & N/A & 2215.04 \\
S1 & 11.09 .07 & -5.1 & 88 & 1.75 & 36.37 & 0.14 & 28.48 & N/A & 2.40 & 41.52 & 0.34 & N/A \\
S2 & 12.09 .07 & -12.4 & 179 & 0.92 & 52.21 & 0.36 & 32.07 & N/A & 2.35 & 68.24 & 9.69 & N/A \\
S3 & 14.09 .11 & -8.3 & 138 & 1.17 & 40.07 & 0.25 & 28.15 & N/A & 4.06 & 49.46 & N/A & N/A \\
S5 & 18.09 .11 & -9.3 & 153 & 0.64 & 45.91 & 0.18 & 28.18 & N/A & 1.59 & 55.68 & 5.89 & N/A \\
S6 & 21.09 .07 & -7.8 & 132 & 1.57 & 45.52 & 0.25 & 28.64 & N/A & 0.98 & 67.31 & 1.47 & N/A \\
S7 & 22.09 .07 & N/A & N/A & N/A & N/A & N/A & N/A & N/A & N/A & N/A & 0.28 & N/A \\
S8 & 25.09 .07 & -3.9 & 73 & 1.93 & 52.25 & 0.13 & 29.93 & N/A & 3.55 & 61.38 & 0.49 & N/A \\
S9 & 28.09 .07 & N/A & N/A & N/A & N/A & N/A & N/A & N/A & N/A & N/A & 0.87 & N/A \\
S10 & 30.09 .07 & -5.0 & 97 & 2.78 & 55.56 & 0.16 & 33.89 & N/A & 3.89 & 43.33 & 0.70 & N/A \\
S11 & 03.10 .07 & -5.1 & 98 & 0.07 & 54.95 & 0.04 & 3.15 & N/A & 4.90 & 73.15 & N/A & N/A \\
S13 & 06.10 .07 & -3.7 & 78 & 1.44 & 42.63 & 0.10 & 23.78 & N/A & 4.94 & 73.14 & N/A & N/A \\
S14 & 07.10 .07 & -5.2 & 78 & 0.27 & 46.92 & 0.13 & 10.00 & N/A & 5.00 & 67.31 & 1.71 & N/A \\
\hline
\end{tabular}




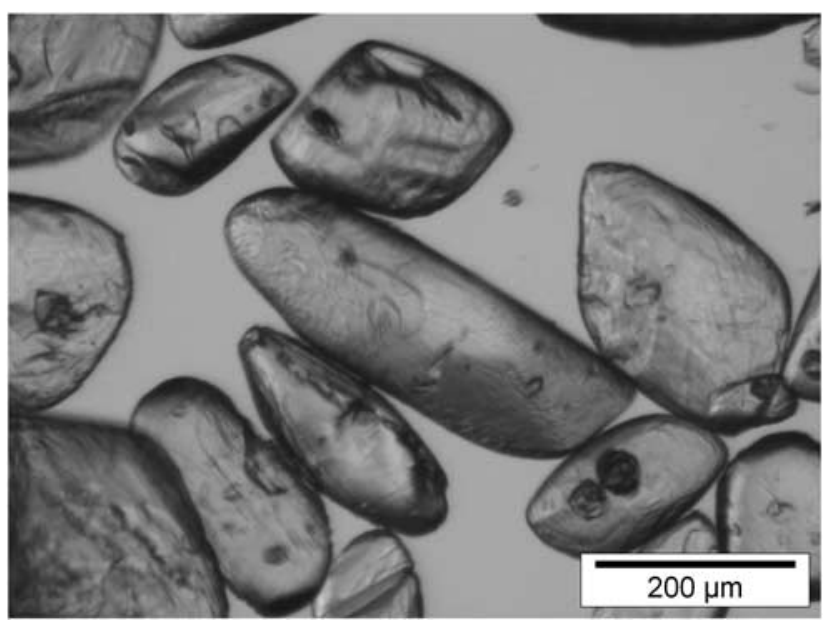

Fig. 4. Light microscopy image of ikaite crystals taken from a single bulk sea ice sample from land fast ice off Terre Adélie.

$10 \mathrm{~cm}$ sections and stored as described above. In order to determine small-scale vertical distribution of ikaite, we also collected four surface cores (D7-D10) between 10 and $15 \mathrm{~cm}$ length (Table I). Cores D7 and D9 were taken from the main sampling site without any snow on top, while D8 was taken next to it and included snow. Ice sample D10 was taken from older fast ice $c .200 \mathrm{~m}$ away from the main sampling site. Ice core D10 was taken from sea ice, which had formed in autumn and had remained intact since its formation, in contrast to cores D1-D9, which were from younger sea ice. Ice cores D7-D10 were cut into $2 \mathrm{~cm}$ sections. In addition, to determine horizontal spatial variability of calcium carbonate, we chose an area $50 \mathrm{~m}$ away from the first sampling site.

On this site the first top $10 \mathrm{~cm}$ of fast ice were sampled every $5 \mathrm{~m}$ (x and y direction) in a grid of $20 \mathrm{mx} 20 \mathrm{~m}$ (D-SP1 to D-SP25, Table I). The partial ice cores obtained were stored in clean plastic containers. At the main sampling site, sackholes (D-SH1 to D-SH7) of $30 \mathrm{~cm}$ were cored every two or three days for a temporal analysis of brine and ice. All samples were collected within an area of $10 \mathrm{~m} \times 10 \mathrm{~m}$ to minimize bias due to spatial heterogeneity. The partial ice cores obtained from these sackholes were also stored in clean plastic containers. Brine was allowed to accumulate in the sackholes and sampled with a vacuum pump and transferred into different vials for total alkalinity (TA), dissolved organic carbon (DOC), dissolved organic nitrogen (DON), and phosphate analyses. Samples for DOM and nutrients were collected as described by Norman et al. (2011) and kept frozen until analyses within six months. The TA samples were measured directly in the base laboratory.

Two sediment traps MST6 (HYDRO-BIOS, $0.005 \mathrm{~m}^{2}$ surface) and a current-meter RCM7 (ANDERRA) were deployed under the sea ice at Dumont d'Urville from 13 November 2007 to 4 December 2007 immediately

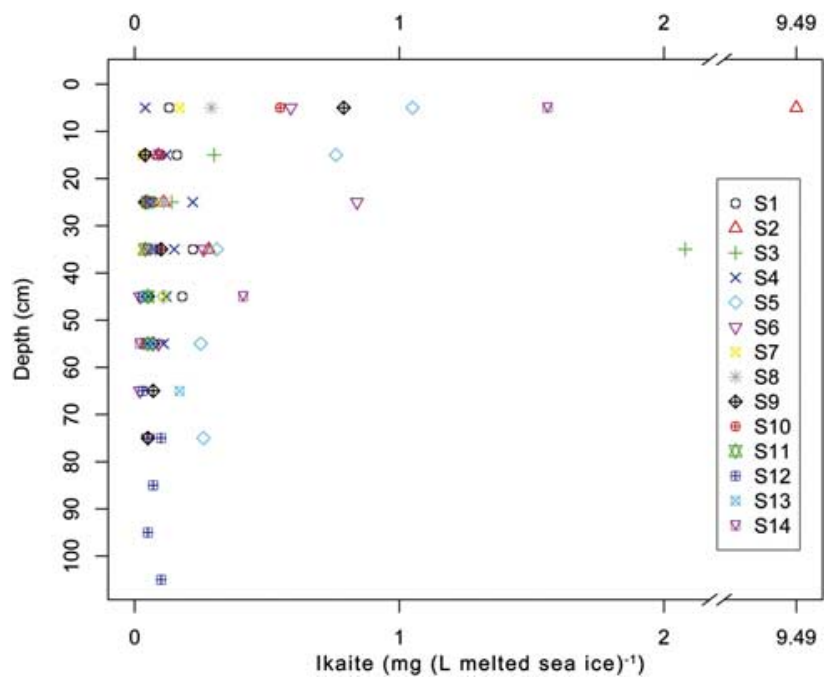

Fig. 5. Distribution of ikaite in sea ice during SIPEX cruise in different ice cores taken between September and October 2007 in East Antarctic.

adjacent to the temporal study site. The first sediment trap was at $5 \mathrm{~m}$ under the ice and the second one at $25 \mathrm{~m}$. Water depth at the site was $53 \mathrm{~m}$. Mercuric chloride was used for fixation of the samples. Sediment trap samples were immediately analysed under the binocular microscope after the traps were retrieved.

We also sampled glacial firn ice $6 \mathrm{~km}$ away from the ice shelf at Cape André Prud'homme to test if calcium carbonates are found on the ice shelf in this region. One surface core $(1 \mathrm{~m})$ was collected and cut into three equal sections. The sections were stored in plastic containers and brought to the base laboratory.

All sea ice samples were slowly melted in a climate controlled room where the temperatures never exceeded $4^{\circ} \mathrm{C}$ to avoid decomposition of the mineral ikaite. Regular monitoring

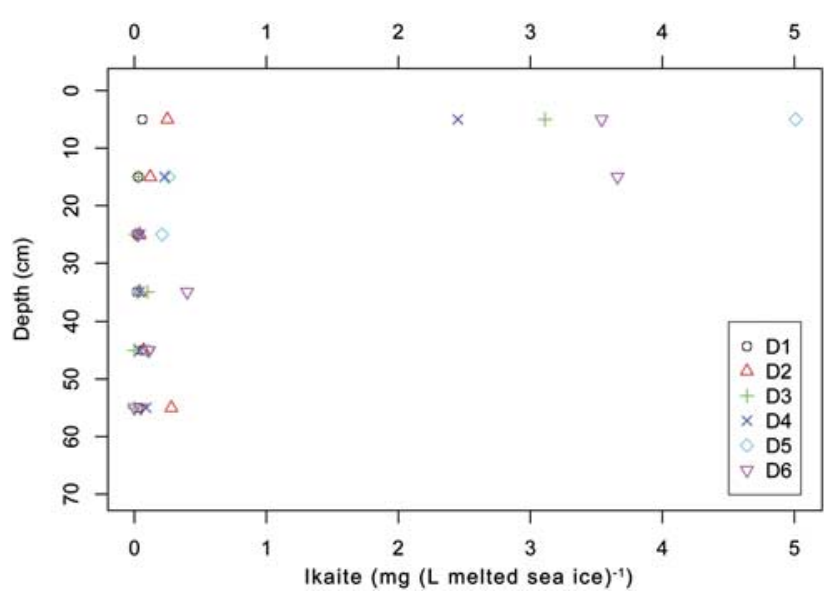

Fig. 6. Distribution of ikaite in sea ice during Dumont d'Urville campaign in land fast sea ice off Terre Adélie sampled in November 2007. 


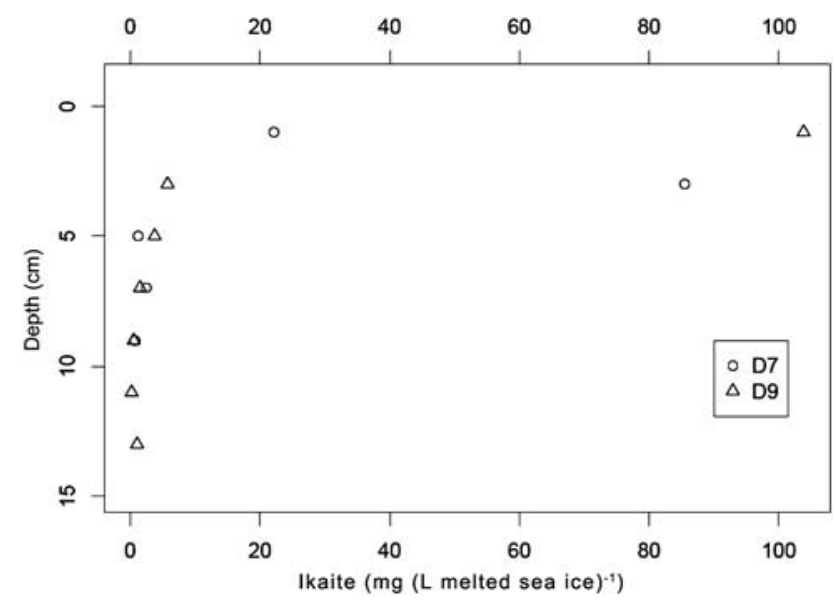

Fig. 7. Distribution of ikaite in the surface layer of young (three month) land fast sea ice off Terre Adélie (Dumont d'Urville).

(several times a day) guaranteed a processing of the samples as soon as the cores or sections were melted. This ensured that the temperature of the meltwater never rose above $0^{\circ} \mathrm{C}$. The meltwater was filtered through $0.2 \mu \mathrm{m}$ polycarbonate filters using a vacuum pump and the volume of filtrate measured. The filters with crystals were placed in plastic vials ( $2 \mathrm{ml}$ Safe-Lock tubes, Eppendorf, Germany) and subsequently filled with $75 \% \mathrm{v} / \mathrm{v}$ ethanol and frozen at $-18^{\circ} \mathrm{C}$ for later mineralogical phase identification and quantitative measurements. In several instances crystals were collected after swirling the melted samples and allowing crystals to settle in the resulting vortex. The crystals were transferred from the vortex to a petri dish using a glass pipette (Dieckmann et al. 2008). These were briefly inspected under the binocular microscope and photographed to check the morphology and subsequently also filtered as described above.

Mineral phase identification was conducted by micro X-ray diffraction $(\mu$-XRD) under cryogenic conditions on selected

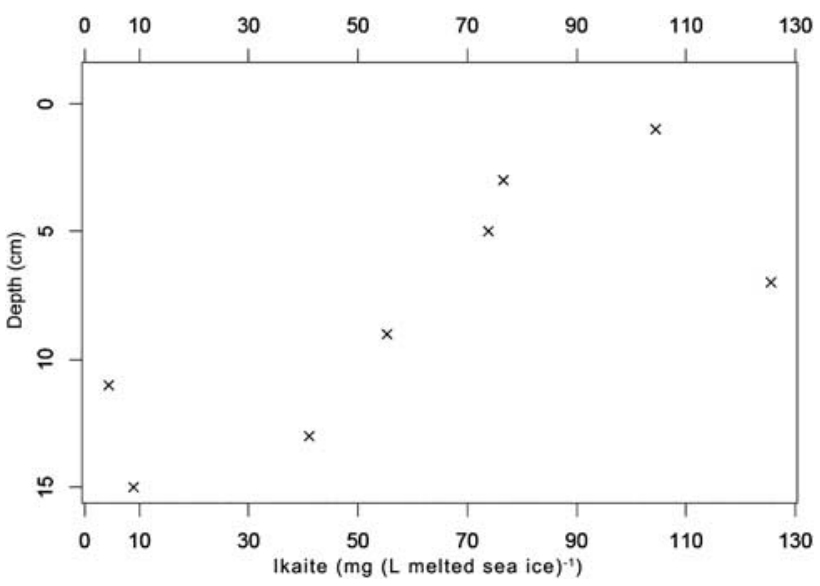

Fig. 8. Distribution of ikaite in the top layer of older (one year) land fast sea ice, off Terre Adélie (Dumont d'Urville) in November 2007 core D10.

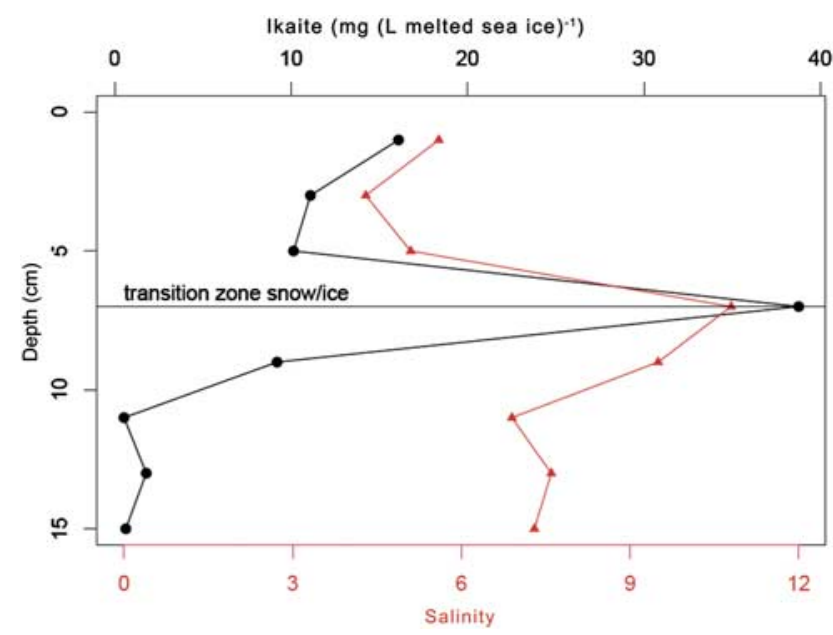

Fig. 9. Distribution of ikaite across the snow-ice interface from top layer of land fast sea ice off Terre Adélie (Dumont d'Urville) in November 2007, core D8. Black line = amount of ikaite, red line $=$ bulk salinity, in contrast to the general use of the $0 \mathrm{~cm}$ for the snow/ice interface, here it indicates the top of the snow.

samples at the Synchrotron Laboratory for Environmental Studies SUL-X at the synchrotron radiation source ANKA, Forschungszentrum Karlsruhe (now Karlsruhe Institute of Technology) as described by Dieckmann et al. (2008).

To quantify the calcium carbonate within a sample, the quantity of calcium ions were determined using

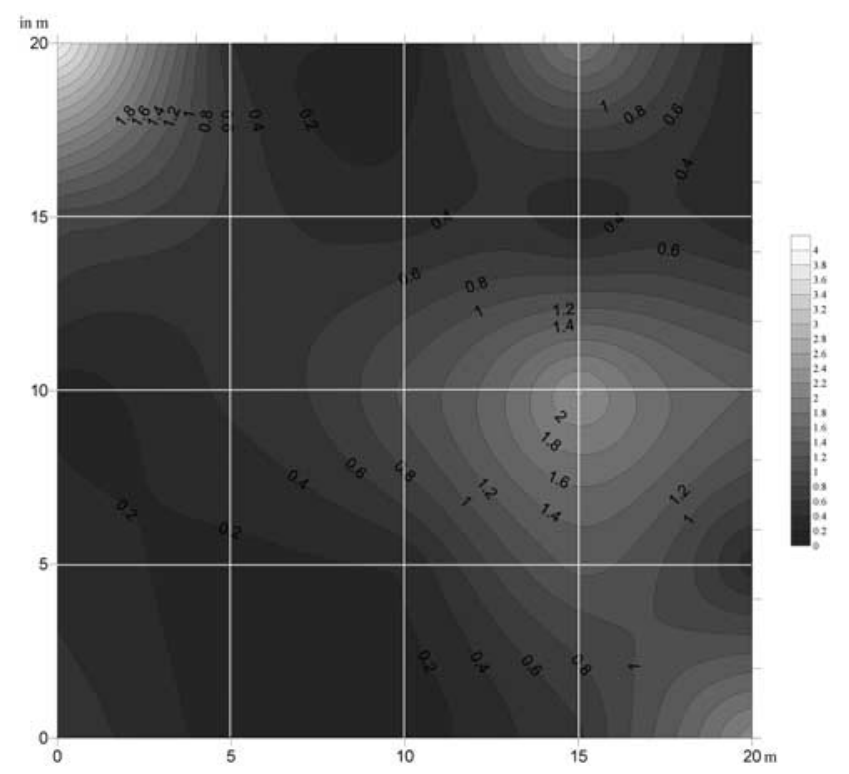

Fig. 10. Contour plot of the spatial distribution of ikaite in the upper $10 \mathrm{~cm}$ of land fast sea ice off Terre Adélie (Dumont d'Urville) in November 2007 on a $20 \mathrm{~m}$ x $20 \mathrm{~m}$ grid with sample points every $5 \mathrm{~m} \times 5 \mathrm{~m}$ (shown by intersections of the white lines and at the edges). Values are in $\mathrm{mg}$ ikaite $1^{-1}$ melted sea ice. 

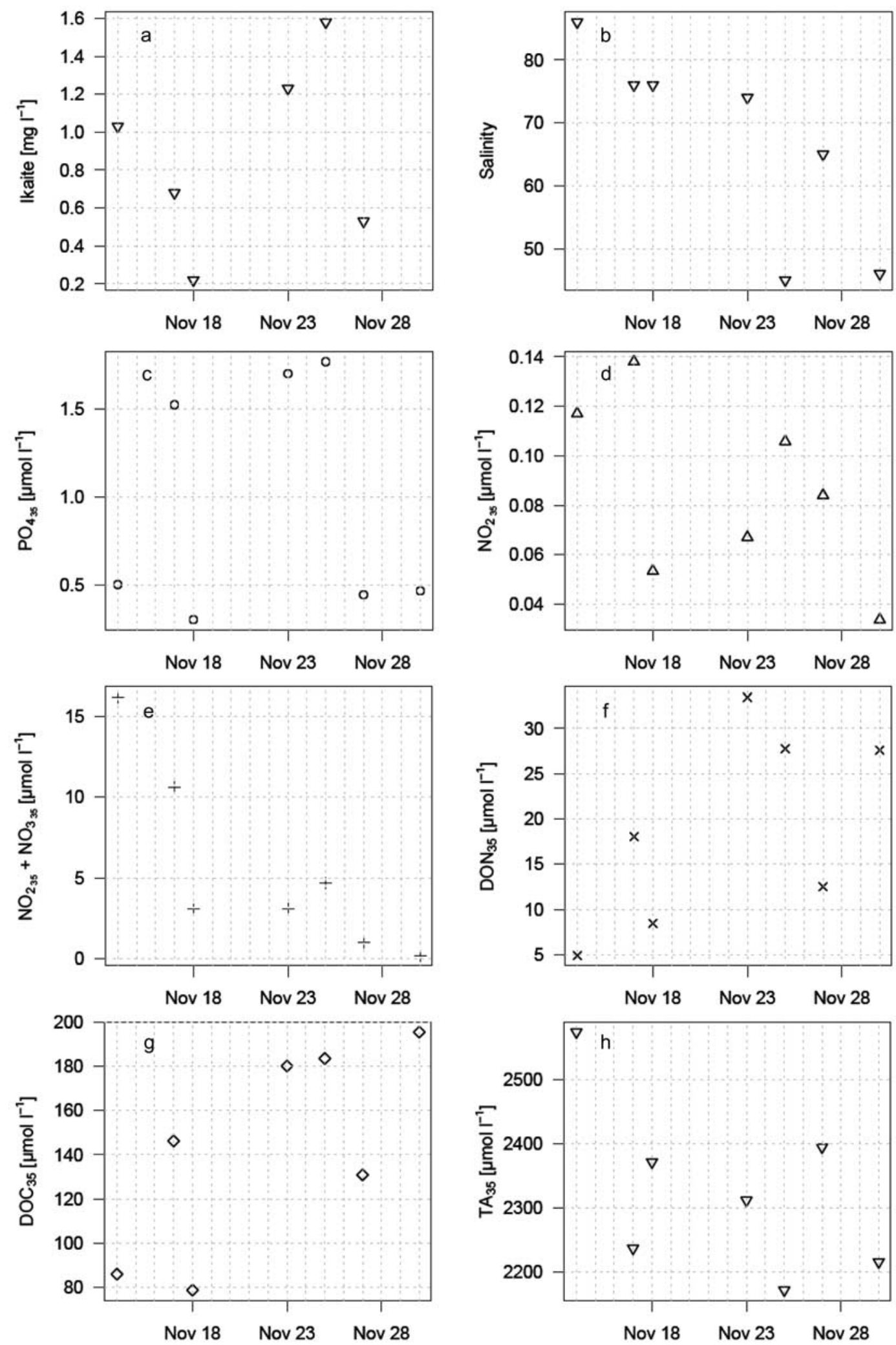

Fig. 11. a. Temporal observation of ikaite in ice cores $(30 \mathrm{~cm})$ obtained from sackholes D-SH1 to D-SH7 (Dumont d'Urville (DDU) campaign), b. salinity, c. salinity-normalized $\mathrm{PO}_{4}{ }^{2-}$, d. $\mathrm{NO}_{2}^{-}$, e. $\left(\mathrm{NO}_{2}\right)+\left(\mathrm{NO}_{3}{ }^{-}\right)_{35}$, f. dissolved organic nitrogen (DON), g. dissolved organic carbon (DOC), and h. total alkalinity (TA) in Antarctic land fast sea ice, off Terre Adélie (DDU) in November 2007. 
Inductively-Coupled Plasma Optical Emission Spectrometry (ICP OES). The Safe-Lock tubes containing the filters were rinsed with concentrated ethanol and the content was transferred to larger vials. The transferred samples were dried at $60^{\circ} \mathrm{C}$ until all the ethanol had evaporated, leaving only the calcium carbonate crystals. Five ml concentrated $\mathrm{HNO}_{3}$ was added to dissociate all molecules according to Eq. (1) before the samples were analysed in the ICP OES. The amount of ikaite was calculated using a molar calcium/ikaite ratio of one.

$$
\left[\mathrm{CaCO}_{3}{ }^{*} 6 \mathrm{H}_{2} \mathrm{O}\right]=\left[\mathrm{Ca}^{2+}\right]+\left[\mathrm{CO}_{3}{ }^{2-}\right]+6\left[\mathrm{H}_{2} \mathrm{O}\right]
$$

Brines from sackholes (D-SH1 to D-SH7 and from ten ice stations during the SIPEX campaign) were analysed for in situ concentrations of phosphate, DON, DOC and alkalinity (Table II). Analysis for the major dissolved inorganic nutrients, nitrate $\left(\mathrm{NO}_{3}^{-}\right)$, nitrite $\left(\mathrm{NO}_{2}^{-}\right)$, and of dissolved inorganic phosphorus (DIP) was done using standard colorimetric methodology (Hanson \& Koroleff 1983) as adapted for flow injection analysis (FIA) on a LACHAT Instruments Quick-Chem 8000 autoanalyzer (Hales et al. 2004). Dissolved organic carbon was analysed by high temperature combustion on an MQ1000 TOC analyser according to Qian \& Mopper (1996). Dissolved organic nitrogen was determined by subtraction of $\mathrm{NO}_{3}{ }^{-}$and $\mathrm{NH}_{4}{ }^{+}$ from the total dissolved nitrogen (TDN) analysed using online peroxodisulfate oxidation coupled with ultraviolet radiation at pH 9.0 and $100^{\circ} \mathrm{C}$ (Kroon 1993). Total alkalinity (D-SH1 to D-SH7) was measured at the station laboratory within one day of sampling as described by Nomura et al. (2010).

For the spatial analysis of the horizontal distribution of $\mathrm{CaCO}_{3} * 6 \mathrm{H}_{2} \mathrm{O}$ a conventional geostatistical spatial interpolation was applied by using the simple kriging method (Sarma 2009).

\section{Results}

Calcium carbonate crystals were found in all samples analysed, including snow, sea ice and glacial ice. Mineral phase identification of selected samples confirmed that ikaite was the precipitate present. Since all crystals extracted from the ice cores showed the same morphological features, it is most likely that the XRD identification as ikaite is representative for all crystals found in this study (Fig. 4). Ikaite concentrations in melted sample (sea ice or snow) ranged from $0.01-126 \mathrm{mgl}^{-1}$ (Table $\mathrm{S} 1$, which will be found at http://dx.doi.org/10.1017/S0954102012001150) and $0.07-0.12 \mathrm{mgl}^{-1}$ in glacial ice. The maximum amount of ikaite was found in older fast ice (D10). Data from 14 ice cores of the SIPEX campaign show the highest concentrations of the ikaite crystals in the upper layers of ice (Fig. 5). Although the highest concentration of ikaite in melted sea ice in the pack ice samples was $9.5 \mathrm{mg}^{\text {ikaite }}{ }^{-1}$, most of the values in the uppermost $10 \mathrm{~cm}$ did not exceed
$2 \mathrm{mg}$ ikaite $\mathrm{l}^{-1}$. Below a depth of $20 \mathrm{~cm}$ (with the exception of two ice cores ( $\mathrm{S} 3$ and $\mathrm{S} 6$ )) in the pack ice, ikaite concentrations ranged between $0.02-0.3 \mathrm{mg} \mathrm{l}^{-1}$. Ice texture analyses of cores S3 and S6 showed it to be rafted sea ice (Meiners et al. 2011).

The ikaite concentrations in land fast ice off Terre Adélie were of a similar magnitude, but generally higher than the pack ice cores (Fig. 6): most were between 2 and $5 \mathrm{mg} \mathrm{l}^{-1}$ in the top layer. A higher resolution sampling $(2 \mathrm{~cm})$ over the first $10-15 \mathrm{~cm}$ showed that the highest concentrations of the mineral were in the top $2-4 \mathrm{~cm}$ of the cores (Fig. 7). Ice core D10 (Fig. 8) was sampled from a separate older fast ice (ice thickness $133 \mathrm{~cm}$ ) location, $200 \mathrm{~m}$ away from the initial sampling site. This core had higher mineral concentrations than those from the younger sea ice. Ice core D8 from snow covered ice (Fig. 9) had ikaite crystals throughout the sample and even in the snow itself. The highest concentration $\left(38.77 \mathrm{mgl}^{-1}\right)$ was measured at the snow/ice interface. The shapes of salinity profiles were similar to those of the amount of ikaite in core D8 (Fig. 9).

A temporal change in ikaite concentration was not observed during the sampling between 14 and 27 November 2007 at DDU. Values measured in the temporal and spatial experiment were in the same range $(0.06$ and $3.93 \mathrm{mgl}^{-1}$, Figs $10 \& 11$, Table II). Hence, we could not differ temporal from spatial heterogeneity. The spatial experiment showed that the distribution of ikaite in sea ice can be highly heterogeneous. $\mathrm{No} \mathrm{CaCO}_{3}$ crystals were found in the sediment traps.

When brine concentrations are normalized to a salinity of $35, \mathrm{DON}_{35}$ and $\mathrm{DOC}_{35}$ concentrations increased non-linearly over a period of time. During the DDU campaign, $\mathrm{DIP}_{35}$ (normalized to $\mathrm{S}=35$ ) shows the same trend as $\mathrm{DON}_{35}$ and $\mathrm{DOC}_{35}$ at the beginning, it did not increase over time and remained low. Only $\mathrm{NO}_{3}{ }^{-}$showed a trend, which might indicate biological activity, although no biological parameters were measured in these samples. Total alkalinity fell from almost 2600 to $c$. $2200 \mu \mathrm{moll}^{-1}$ and did not show a linear trend, similar to the other measured chemical parameters. Neither DIC, DON, DOC concentrations (from SIPEX and DDU campaign) nor TA (DDU campaign) correlated significantly with the amount of ikaite present in the ice horizons from where the brines were collected. Comparison of theoretical values of brine salinity (calculated according to Petrich \& Eicken 2010) versus measured values (Table II) showed no significant differences. Thus, brine volumes, although being above $5 \%$, most probably were low enough to prevent influences by seawater.

\section{Discussion}

These results together with previous observations (Dieckmann et al. 2008) indicate that calcium carbonate precipitation is widespread in Antarctic sea ice, albeit 
highly spatially heterogeneously, as is the case for many other biogeochemical parameters in sea ice (Thomas \& Dieckmann 2010). Although we were not able to verify the $\mathrm{CaCO}_{3}$ polymorph for each sample collected, the visual characterization by light microscopy confirmed that the morphology of all crystals was identical to those analysed by X-ray diffraction. We are therefore convinced that ikaite was always the precipitate. Higher brine salinities in the uppermost layers, resulting from lower temperatures at the sea ice surface, and correspondingly high $\Omega_{\text {ikaite }}$ (ikaite saturation state of seawater) values, resulted in a more likely precipitation of ikaite near the ice surface than in lower parts in sea ice where temperatures are higher and brine salinity can drop to seawater values. However, it is still not clear at what point in time ikaite precipitation occurs, and our interpretation is confounded because the various biogeochemical parameters measured during sample collection do not reflect conditions at the time of precipitation. For example the question arises why a TA decrease by $400 \mu \mathrm{mol}$ did not result in a correlation with the precipitation of ikaite. As discussed above, the measurements reflect only a small time frame in the seasonal carbon cycle within sea ice and not necessarily the conditions at time of precipitation. Observations of higher values of ikaite in older land fast ice (Fig. 8) also raise the question of whether or not precipitation can take place during subsequent sea ice growth, or if ikaite, after it has formed in young sea ice remains stable under various conditions until the sea ice melts thereby not altering TA or the carbonate system itself.

Based on a thermo-molecular pressure gradient as described by Wettlaufer \& Worster (1995), brine, as unfrozen liquid, can be transported from the ice interior toward the relatively colder surface (Rankin \& Wolff 2002). The accumulated brine at the surface has a salinity of about 100 (Perovich \& Richter-Menge 1994) and favours the precipitation of salts. Under those conditions frost flowers may start to grow (Perovich \& Richter-Menge 1994, Rankin \& Wolff 2002) and in turn can initiate $\mathrm{CaCO}_{3}$ precipitation. However, conditions not necessarily leading to frost flower formation, may also lead to $\mathrm{CaCO}_{3}$ precipitation if the temperature is low and salinity is high. The occurrence of calcium carbonate in the snow cover can most probably also be explained by the thermo-molecular pressure gradient and capillary transport. Brine is transported due to these processes into the snow where subsequently the precipitation of ikaite occurs. This is supported by the maximum concentrations of ikaite at the snow ice interface (Fig. 9). It is plausible that ikaite was there before snow accumulation, but this would not explain the different values in different snow layers.

Higher values of calcium carbonate in some middle layers of sea ice (S3 in Fig. 5) were attributable to rafting of floes subsequent to sea ice formation (see Meiners et al. 2011). Pack ice may be subject to deformation and floes may raft over each other resulting in the translocation of surface layers into interior layers of the newly established ice floe.

It is not possible to determine the temporal development of $\mathrm{CaCO}_{3}$ in the sea ice investigated during the DDU campaign. This is due to the large variability in $\mathrm{CaCO}_{3}$ concentrations even on small spatial scales. The reason for this heterogeneity might be due to the inherent variability in many sea ice properties ranging from temperature, salinity, texture, chemistry, as well as biological activity. The spatial heterogeneity is already apparent on small scales as shown by the spatial study during the DDU campaign. Thus, it is difficult to draw conclusions on the temporal evolution of the precipitation of ikaite. Although $\mathrm{CaCO}_{3}$ concentrations were in the same order of magnitude in pack ice and land fast ice there appear to be differences in the amount of precipitated calcium carbonate indicating a potential temporal evolution. The highest values were recorded in approximately one-year-old land fast sea ice, followed by high amounts in land fast ice and the lowest concentrations in pack ice. The processes responsible for the observed differences in ikaite concentrations in the different types of sea ice observed remain unclear. One explanation could be that $\mathrm{CaCO}_{3}$ is also precipitating during subsequent sea ice growth. Another reason could be that sea ice is experiencing different growth conditions, e.g. higher temperatures resulting in lower salinities and saturation states and thus lower values of ikaite.

The high concentrations of DOC and DON found in fast ice off Terre Adélie were expected to inhibit $\mathrm{CaCO}_{3}$ precipitation (Bischoff et al. 1993). Zullig \& Morse (1988) and Berner et al. (1978) showed that DOM influences the precipitation of some polymorphs of calcium carbonate. However, these studies refer only to the inhibition for anhydrous polymorphs of $\mathrm{CaCO}_{3}$. Besides the repression by polyphosphate and magnesium ions on the precipitation of anhydrous calcium carbonate in favour of hydrated forms, Dickens \& Brown (1970) postulated that hydrated salts may play an important part in biological mineralization. Taking this into account, additionally to the elevated $\Omega_{\text {ikaite, }}$, microbial biomass, such as cell surfaces and/or extracellular polymeric substances, could catalyse the precipitation of calcium carbonate (Kandianis et al. 2008). This also coincides with findings of elevated abundance of bacteria and exopolymers in frost flowers (Bowman \& Deming 2010) and the top layer of experimentally formed sea ice (Aslam et al. 2012), which supports the hypothesis of $\mathrm{CaCO}_{3}$ precipitation during frost flower and initial sea ice formation as discussed above.

The reasons why we did not find $\mathrm{CaCO}_{3}$ in the sediment trap are not clear and the absence can at this stage only be attributed to several factors, which cannot be verified. These include the dissolution of crystals during ice melt, which means crystals do not leave the sea ice as temperatures increase (Rysgaard et al. 2012). 
The dissolution occurred in the sediment trap itself before the trap was retrieved, but this would mean that crystals, which dropped out of the ice a day before retrieval would also have dissolved.

Previous studies have pointed out the importance of sea ice for the carbon uptake in polar oceans due to $\mathrm{CaCO}_{3}$ precipitation (Nedashkovsky et al. 2009, Rysgaard et al. 2009, 2011). An estimation of the contribution of calcium carbonate precipitation to the polar carbon cycle would be useful. However, the large heterogeneity observed in the distribution of ikaite will make such an estimate highly uncertain. Yet, based on our observations we propose a first estimate of the possible contribution of calcium carbonate precipitation to the carbon cycle. For simplicity we take into account only the top $10 \mathrm{~cm}$ of sea ice, since the amount in the lower part was negligible. Absolute values of ikaite found in the top $10 \mathrm{~cm}$ of sea ice ranged between 0.1 and $6.5 \mathrm{~g} \mathrm{~m}^{-2}$. Based on the total seasonal ice cover in the Antarctic (Comiso 2010) we calculate that $\mathrm{CaCO}_{3}$ formation in sea ice potentially could represent a contribution of between 0.1 and $6 \mathrm{TgC}$ to the carbon flux in the Southern Ocean. Assuming the same distribution in Arctic sea ice together with the ice cover from Comiso \& Nishio (2008) then the precipitation of $\mathrm{CaCO}_{3}$ would be responsible for a flux between 0.04 and $3 \mathrm{TgC}$. For both the Arctic and Antarctic this would be between $0.1 \%$ and $4.5 \%$ of the air-sea $\mathrm{CO}_{2}$ flux in open oceanic water at high latitudes (Takahashi et al. 2009, Rysgaard et al. 2011) or up to $13 \%$ for the Southern Ocean south of $50^{\circ}$ (Takahashi et al. 2009). Although there is a large amount of ikaite in the snow, the amount of $\mathrm{CaCO}_{3}$ therein was not taken into account for the calculation, since the distribution of $\mathrm{CaCO}_{3}$ crystals in the snow remains elusive. However, if widespread this would be a significant addition to the polar carbon flux.

In addition, considering polynyas with new sea ice forming during the winter, and assuming that $\mathrm{CaCO}_{3}$ precipitation mainly occurs during young sea ice and frost flower formation, this phenomenon might then contribute even to a larger extent to the air-sea flux. However, this would only be the case if $\mathrm{CO}_{2}$, which is released during $\mathrm{CaCO}_{3}$ precipitation, is rejected to the underlying water column. Yet, polynyas are still poorly understood with respect to gas fluxes (Else et al. 2011). Therefore it is essential to determine and quantify the $\mathrm{CO}_{2}$ pathways during sea ice formation to fully quantify the contribution of calcium carbonate precipitation to the air-sea $\mathrm{CO}_{2}$ flux. The fact that ikaite is mainly formed at the surface of sea ice adds support to the work of Sander et al. (2006) and Sander \& Morin (2010) which described the contribution of $\mathrm{CaCO}_{3}$ precipitation to ozone depletion events. It also supports the work of Sala et al. (2008), since ikaite crystals at the snow-ice interface and in the snow are more likely exposed to aeolian transport and could therefore serve as sea ice proxy.

\section{Conclusions}

This study provides an investigation of the spatial and temporal distribution of $\mathrm{CaCO}_{3}$ in sea ice. We showed the heterogeneous occurrence of $\mathrm{CaCO}_{3}$ in sea ice. Large-scale quantification of $\mathrm{CaCO}_{3}$ precipitation in different types of sea ice and during the entire season in both the Arctic and Antarctic is necessary to validate these findings and to provide a quality dataset to estimate its contribution to the polar carbon cycle. Since parameters measured during sample collection do not reflect conditions at the time of precipitation, much work is needed to evaluate the conditions of calcium carbonate precipitation within sea ice and its fate during sea ice melt.

\section{Acknowledgements}

We thank the EPONTA (EPONTic micro-algae adapted to sea ice) program for funding and Institut Polaire Francais, Paul-Émile Victor (IPEV) for logistical assistance during the DDU campaign. We thank Harald Zöller, Thomas Spangenberg, Michael Wünsch, and Karlheinz Cerff for technical and computing support before and during the measurements, as well as Christiane Uhlig for preparing the samples for mineralogy and synthetic ikaite. We also thank Frank Gérard, all the scientists, and technicians from the French research station Dumont d'Urville, Antarctica as well as the captain and crew of the polar vessel Astrolabe and the pilots of the Australian Antarctic Division for all their help and support. Andreas Krell, Louiza Norman, and Klaus Meiners are particularly grateful for the support of the SIPEX team and crew of Aurora Australis, especially the expedition leader Tony Worby. David Thomas and Louiza Norman thank NERC (UK) and the Leverhulme Trust for funding. We thank the DFG for financial support through grant NE 1564/2-1 (SPP1158). This project was supported by the Australian Government Co-operative Research Centre Program through the Antarctic Climate and Ecosystems Co-operative Research Centre (ACE CRC) and through Australian Antarctic Science grant \#2767. The constructive comments of the reviewers are gratefully acknowledged.

\section{Supplemental material}

A supplemental table will be found at http://dx.doi.org/ 10.1017/S0954102012001150.

\section{References}

Anderson, L.G. \& Jones, E.P. 1985. Measurement of total alkalinity, calcium, and sulfate in natural sea ice. Journal of Geophysical Research, 90, 9194-9198.

Aslam, S., Uunderwood, G.J.C., Kaartokallio, H., Norman, L., Autio, R., Fischer, M., Kuosa, H., Dieckmann, G.S. \& Thomas, D.N. 2012. Dissolved extracellular polymeric substance (dEPS) dynamics and bacterial growth during sea ice formation in an ice tank study. Polar Biology, 35, 661-676. 
Berner, R.A., Westrich, J.T., Graber, R., Smitz, J. \& Martens, C.S. 1978. Inhibition of aragonite precipitation from supersaturated seawater. American Journal of Science, 278, 816-837.

Bischoff, J.L., Fitzpatrick, J.A. \& Rosenbauer, R.J. 1993. The solubility and stabilization of ikaite $\mathrm{CaCO}_{3} * 6 \mathrm{H}_{2} \mathrm{O}$ from $0^{\circ}$ to $25^{\circ} \mathrm{C}$ : environmental and paleoclimatic implications for thinolite tufa. The Journal of Geology, 101, 21-33.

Bowman, J.S. \& Deming, J.W. 2010. Elevated bacterial abundance and exopolymers in saline frost flowers and implications for atmospheric chemistry and microbial dispersal. Geophysical Research Letters, 10.1029/2010GL043020

Comiso, J.C. 2010. Large-scale characteristics and variability of the global sea ice cover. In Thomas, D.N. \& Dieckmann, G.S., eds. Sea ice: an introduction to its physics, chemistry, biology and geology. Oxford: Wiley-Blackwell, 205-246.

Comiso, J.C. \& Nishio, F. 2008. Trends in the sea ice cover using enhanced and compatible AMSRE, SSM/I, and SMMR data. Journal of Geophysical Research, 10.1029/2007JC004257.

Cox, G.F.N. \& WeEks, W.F. 1986. Changes in the salinity and porosity of sea ice samples during shipping and storage. Journal of Glaciology, 32, 371-375.

Delille, B., Jourdain, B., Borges, A.V., Tison, J.-L. \& Delille, D. 2007. Biogas $\left(\mathrm{CO}_{2}, \mathrm{O}_{2}\right.$, dimethylsulfide) dynamics in spring Antarctic fast ice. Limnology and Oceanography, 52, 1367-1379.

Dickens, B. \& Brown, W.B. 1970. The crystal structure of calcium carbonate hexahydrate at about $-120^{\circ} \mathrm{C}$. Inorganic Chemistry, 9, 480-486.

Dieckmann, G.S., Nehrke, G., Uhlig, C., Göttlicher, J., Gerland, S., GransKog, M.A. \& Thomas, D.N. 2010. Brief communication: ikaite $\mathrm{CaCO}_{3} * 6 \mathrm{H}_{2} \mathrm{O}$ discovered in Arctic sea ice. The Cryosphere, 4, 227-230.

Dieckmann, G.S., Nehrke, G., Papadimitriou, S., Göttlicher, J., Steininger, R., Kennedy, H., Wolf-Gladrow, D. \& Thomas, D.N. 2008. Calcium carbonate as ikaite crystals in Antarctic sea ice. Geophysical Research Letters, 10.1029/2008GL033540.

Else, B.G.T., Papakyriakou, T.N., Galley, R.J., Drennan, W.M., Miller, L.A. \& Thomas, H. 2011. Wintertime $\mathrm{CO}_{2}$ fluxes in an Arctic polynya using eddycovariance: evidence for enhanced air-sea gas transfer during ice formation. Journal of Geophysical Research, 10.1029/2010JC006760.

Hales, B., van GeEn, A. \& TaKahashi, T. 2004. High-frequency measurement of seawater chemistry: flow-injection analysis of macronutrients. Limnology and Oceanography: Methods, 2, 91-101.

HANSON, H. \& KoRolefF, F. 1983. Determination of nutrients. In Grasshoff, K., Ehrhardt, M. \& Kremling, K., eds. Methods of seawater analysis. Weinheim: Verlag Chemie, 159-288.

Jones, E.P. \& CоOTE, A.R. 1981. Oceanic $\mathrm{CO}_{2}$ produced by the precipitation of $\mathrm{CaCO}_{3}$ from brines in sea ice. Journal of Geophysical Research, 86, $11041-11043$.

Kandianis, M.T., Fouke, B.W., Johnson, J.W., Veysey II, J. \& Inskeep, W.P. 2008. Microbial biomass: a catalyst for $\mathrm{CaCO}_{3}$ precipitation in advection-dominated transport regimes. Geological Society of America Bulletin, 120, 442-450.

Killawee, J.A., Fairchild, I.J., Tison, J.-L., Janssens, L. \& Lorrain, R. 1998. Segregation of solutes and gases in experimental freezing of dilute solutions: implications for natural glacial systems. Geochimica et Cosmochimica Acta, 62, 3637-3655.

KRoON, H. 1993. Determination of nitrogen in water: comparison of continuous flow method with online UV digestion with the original Kjedahl method. Analytica Chimica Acta, 276, 287-293.

Loose, B., Miller, L., Elliott, S. \& Papakyriakou, T. 2011. Sea ice biogeochemistry and material transport across the frozen interface. Oceanography, 24, 202-218.

Marion, G.M. 2001. Carbonate mineral solubility at low temperatures in the $\mathrm{Na}-\mathrm{K}-\mathrm{Mg}-\mathrm{Ca}-\mathrm{H}-\mathrm{Cl}-\mathrm{SO} 4-\mathrm{OH}-\mathrm{HCO} 3-\mathrm{CO} 3-\mathrm{CO} 2-\mathrm{H} 2 \mathrm{O}$ system. Geochimica et Cosmochimica Acta, 65, 1883-1896.
Meiners, K.M., Norman, L., Granskog, M.A., Krell, A., Heil, P. \& Thomas, D.N. 2011. Physico-ecobiogeochemistry of East Antarctic pack ice during the winter-spring transition. Deep-Sea Research II, 58, 1172-1181.

Miller, L., Papakyriakou, T.N., Collins, E., Deming, J., Ehn, J.K., MacDonald, R.W., Mucci, A., Owens, O., Raudsepp, M. \& Sutherland, N. 2011. Carbon dynamics in sea ice: a winter flux time series. Journal of Geophysical Research, 10.1029/2009JC006058.

NedashKovsky, A.P., KhVedynich, S.V. \& Petrovsky, T.V. 2009. Alkalinity of sea ice in the high latitudinal Arctic according to the surveys performed at North Pole drifting station 34 and characterization of the role of the Arctic ice in the $\mathrm{CO}_{2}$ exchange. Marine Chemistry, 49, 61-69.

Nomura, D., Yoshikawa-Inoue, H., Toyota, T. \& Shirasawa, K. 2010. Effects of snow, snowmelting and refreezing processes on air-sea ice $\mathrm{CO}_{2}$ flux. Journal of Glaciology, 56, 262-270.

Norman, L., Thomas, D.N., Stedmon, C.A., Granskog, M.A., Papadimitriou, S., Krapp, R.H., Meiners, K.M., Lannuzel, D., van der Merwe, P. \& DiecKMANN, G.S. 2011. The characteristics of dissolved organic matter (DOM) and chromophoric dissolved organic matter (CDOM) in Antarctic sea ice. Deep Sea Research II, 58, 1075-1091.

Papadimitriou, S., Kennedy, H., Kattner, G., Dieckmann, G.S. \& Thomas, D.N. 2004. Experimental evidence for carbonate precipitation and $\mathrm{CO}_{2}$ degassing during sea ice formation. Geochimica et Cosmochimica Acta, 68, 1749-1761.

Papadimitriou, S., Kennedy, H., Norman, L., Kennedy, D.P., Dieckmann, G.S. \& Thомаs, D.N. 2012. The effect of biological activity, $\mathrm{CaCO}_{3}$ mineral dynamics, and $\mathrm{CO}_{2}$ degassing in the inorganic carbon cycle in sea ice in late winter-early spring in the Weddell Sea, Antarctica. Journal of Geophysical Research, 10.1029/2012JC008058.

Perovich, D.K. \& Richter-Menge, J.A. 1994. Surface characteristics of lead ice. Journal of Geophysical Research, 99, 16341-16350.

Petrich, C. \& Eicken, H. 2010. Growth, structure, and properties of sea ice. In Thomas, D.N. \& Dieckmann, G.S., eds. Sea ice: an introduction to its physics, chemistry, biology and geology. Oxford: Wiley-Blackwell, 23-77.

Qian, J. \& Mopper, K. 1996. An automated, high performance, high temperature combustion dissolved organic carbon analyser. Analytical Chemistry, 68, 3090-3097.

Rankin, A.M. \& WolfF, E.W. 2002. Frost flowers: implications for tropospheric chemistry and ice core interpretation. Journal of Geophysical Research, 10.1029/2002JD002492.

Rysgaard, S., Bendtsen, J., Pedersen, L.T., Ramløv, H. \& Glud, R.N. 2009. Increased $\mathrm{CO}_{2}$ uptake due to sea ice growth and decay in the Nordic Seas. Journal of Geophysical Research, 10.1029/2008JC005088.

Rysgaard, S., Glud, R.N., SejR, M.K., Bendtsen, J. \& Christensen, P.B. 2007. Inorganic carbon transport during sea ice growth and decay: a carbon pump in polar seas. Journal of Geophysical Research, 10.1029/ 2006JC003572.

Rysgaard, S., Glud, R., Lennert, K., Cooper, M., Halden, N., Leakey, R.J.G., HAwthorNe, F.C. \& BARBer, D. 2012. Ikaite crystals in melting sea ice - implications for $\mathrm{pCO}_{2}$ and $\mathrm{pH}$ levels in Arctic surface waters. The Cryosphere, 6, 901-908.

Rysgaard, S., Bendtsen, J., Delille, B., Dieckmann, G.S., Glud, R.N., Kennedy, H., Mortensen, J., Papadimitriou, S., Thomas, D.N. \& Tison, J.L. 2011. Sea ice contribution to the air-sea $\mathrm{CO}_{2}$ exchange in the Arctic and Southern oceans. Tellus B, 63, 823-830.

Sala, M., Delmonte, B., Frezzotti, M., Proposito, M., Scarchilli, C., Maggi, V., Artioli, G., Dapiaggi, M., Marino, F., Ricci, P.C. \& De GiUdicI, G. 2008. Evidence of calcium carbonates in coastal (Talos Dome and Ross Sea area) East Antarctica snow and firn: environmental and climatic implications. Earth Planetary Science Letters, 271, 43-52.

SANDER, R. \&, MoRIN, S. 2010. Introducing the bromide/alkalinity ratio for a follow-up discussion on "Precipitation of salts in freezing seawater and ozone depletion events: a status report", by Morin et al., published in Atmospheric Chemistry and Physics, 8, 7317-7324, 2008. Atmospheric Chemistry and Physics, 10, 7655-7658. 
Sander, R., Burrows, J. \& KaleschKe, L. 2006. Carbonate precipitation in brine - a potential trigger for tropospheric ozone depletion events. Atmospheric Chemistry and Physics, 6, 4653-4658.

SARMA, D.D. 2009. Geostatistics with applications in earth sciences. Heidelberg: Springer, 224 pp.

Takahashi T., Sutherland S., Wanninkhof R. et al. 2009. Climatological mean and decadal change in surface ocean $\mathrm{pCO}_{2}$, and net sea-air $\mathrm{CO}_{2}$ flux over the global oceans. Deep-Sea Research II, 56, 554-577.

Thomas, D.N. \& Dieckmann, G.S. 2010. Sea ice: an introduction to its physics, chemistry, biology and geology. Oxford: Wiley-Blackwell, $621 \mathrm{pp}$.
Thomas, D.N., Kattner, G., Engbrodt, R., Giannelli, V., Kennedy, H., Haas, C. \& Dieckmann, G.S. 2001. Dissolved organic matter in Antarctic sea ice. Annals of Glaciology, 33, 297-303.

Wettlaufer, J.S. \& Worster, M.G. 1995. Dynamics of premelted films: frost heave in a capillary. Physical Review, 51, 4679-4689.

Worby, A.P., Steer, A., Lieser, J.L., Heil, P., Yi, D., Markus, T., Allison, I., Massom, R.A., Galin, N. \& Zwally, J. 2011. Regional-scale sea ice and snow thickness distributions from in situ and satellite measurements over East Antarctica during SIPEX 2007. Deep Sea Research II, 58, 1125-1136. Zullig, J.J. \& Morse, J.W. 1988. Interaction of organic acids with carbonate mineral surfaces in seawater and related solutions: I. fatty acid adsorption. Geochimica et Cosmochimica Acta, 52, 1667-1678. 